E-ISSN : $2477-0124$
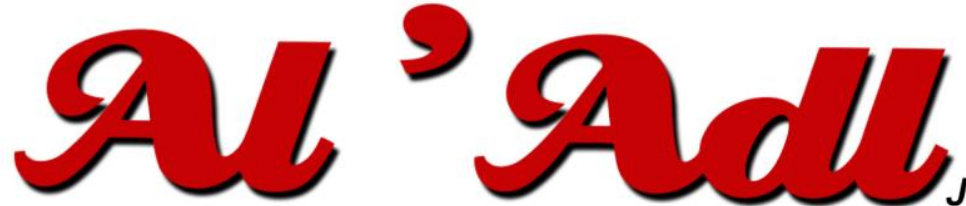

Jurnal Hukum

Editorial Office: Faculty of Law, Islamic University Of Kalimantan,

Jalan Adhyaksa No. 2 Kayutangi Banjarmasin, Kalimantan Selatan, Indonesia (70123)

Email: al_adl@uniska-bjm.ac.id

Web: http://ojs.uniska-bjm.ac.id

\title{
KEJAHATAN PENISTAAN AGAMA DAN KONSEKUENSI HUKUMNYA
}

\author{
${ }^{(1)}$ Muhammad Hatta, ${ }^{(2)}$ Zulfan, ${ }^{*}$ (3) Husni \\ Fakultas Hukum Universitas Malikussaleh, Aceh, Indonesia \\ Kampus Bukit Indah, Jalan Jawa, Blang Pulo, Muara Dua, Kota Lhokseumawe, Aceh - 24355 \\ Email: muhammad.hatta@unimal.ac.id \\ (2) zulfan@ unimal.ac.id, \\ (3) husni@unimal.ac.id.
}

\begin{abstract}
Submitted : 08 April 2021
Revised : 27 April 2021

Accepted :06 Mei 2021

Published : 21 Mei 2021

*Correspondent Author
\end{abstract}

(C) Licence by CC BY-NC-SA

\begin{abstract}
This study aims to analyze the regulation and enforcement of criminal law against the crime of blasphemy (religious defamation). The method used in this research is the normative method which is carried out by examining the laws and regulations that are applied to particular legal problems. The results of this study state that Indonesia recognizes religions and divinity so that the first principles of Pancasila and the Preamble to the 1945 Constitution explicitly state the recognition of divinity by various religions and beliefs. Therefore, every person is obliged to adhere to a certain religion and belief in its truth. However, every religious adherent must maintain harmony between communities both in carrying out their worship and implementing laws that are believed to be true. One of the actions that often trigger clashes between communities is the act of blasphemy. Along with the development of Information and communication technology, acts of blasphemy are widely spread in various virtual media, both on social media and news media. To maintain harmony, the government strictly enforces the law against crimes of religious blasphemy on various laws and regulations such as the Penal Code and Act 19/2016 on Amendments to Act 11/2008. Therefore, all offenders of religious blasphemy in Indonesia will face legal consequences according to their actions.
\end{abstract}

Keywords: Crimes; Defamation; Religion; Legal Consequences

\section{Abstrak}

Penelitian ini bertujuan untuk menganalisis pengaturan dan penegakan hukum pidana terhadap kejahatan penistaan agama. Metode penelitian yang digunakan dalam penelitian ini adalah metode penelitian normatif yakni penelitian hukum yang dilakukan dengan cara mengkaji peraturan perundang-undangan yang diterapkan terhadap suatu permasalahan hukum tertentu. Hasil penelitian ini menyatakan bahwa Indonesia merupakan Negara yang mengakui adanya agama dan ketuhanan sehingga dalam sila pertama Pancasila dan Pembukaan Undang-Undang Dasar Negara Republik Indonesia Tahun 1945 secara tegas menyebutkan pengakuan ketuhanan dengan berbagai agama dan aliran kepercayaa. Oleh karena itu, setiap orang wajib menganut agama dan aliran kepercayaan tertentu yang diyakini kebenarannya. Namun, setiap pemeluk agama harus menjaga kerukunan antar umat beragama baik dalam menjalankan ibadahnya maupun melaksanakan hukum yang diyakini 
kebenarannya. Salah satu tindakan yang sering memicu pertikaian antar umat beragama adalah tindakkan penistaan agama. Seiring dengan perkembangan teknologi Informasi dan komunikasi (Informatika), tindakkan penistaan agama, banyak tersebar di berbagai media virtual baik di media social maupun media pemberitaan. Untuk menjaga kerukunan umat beragama, pemerintah secara tegas melakukan penegakkan hukum terhadap pelaku penistaan agama berdasarkan berbagai Peraturan Perundang-Undangan seperti Kitab Undang-Undang Hukum Pidana (KUHP) dan Undang-Undang Nomor 19 Tahun 2016 tentang Perubahan Atas Undang-Undang Nomor 11 Tahun 2008. Oleh karena itu, semua pelaku penistaan agama akan mendapatkan konsekuensi hukum sesuai dengan perbuatannya.

Kata Kunci : Kejahatan, Penistaan, Agama, Konsekuensi Hukum.

\section{PENDAHULUAN}

Kebebasan beragama di Indonesia bukanlah bersifat absolut dimana para penganutnya dapat menjalankan ibadah dan kepercayaannya sesuka hatinya, tanpa memperhatikan dan menghormati penganut agama lain yang sudah lama ada dan hidup berdampingan secara turun temurun. Untuk menertipkan penganut agama dalam menjalankan ibadah dan kepercayaannya maka pemerintah menerbitkan Peraturan Perundang-Undangan dengan tujuan menjaga kerukunan umat beragama. ${ }^{1}$ Menurut Winkle, setiap negara di dunia memberlakukan suatu aturan untuk menjamin kebebasan beragama dan membuat berbagai batasan untuk menjaga kerukunan umat beragama. ${ }^{2}$ Apabila tidak diatur sedemikian rupa maka kebebasan beragama seseorang atau sekelompok tertentu dapat menganggu kebebasan orang lain dalam menjalankan ajaran agamnya.

Dalam konstitusi kita, ada berbagai instrument yang menjamin dan melindungi kebebasan beragama. Misalnya, Pasal 28 huruf E Undang-Undang Dasar Negara Republik Indonesia Tahun 1945 menentukan bahwa setiap orang berhak memeluk agama dan beribadat menurut agamanya, memilih pendidikan dan pengajaran, memilih pekerjaan, memilih

\footnotetext{
${ }^{1}$ Tidak hanya Indonesia yang menempatkan kebebasan beragama secara formal yuridis dalam konteks perlindungan hak asasi manusia. Jepang juga salah satu negara yang menempatkan kebebasan beragama sebagai hal penting dalam kehidupan bernegara. Meskipun pernah diberlakukan Buddhisme sebagai agama negara pada jaman Tokugawa dan Shinto pada jaman Meiji, ide kebebasan beragama termanifestasikan dalam Article 28 pada Imperial Constitution of the Great Empire of Japan pada tahun 1889 yang menyatakan "Japanese subjects shall, ..., enjoy freedom of religious belief". Menurut Hori Ichiro, kebebasan beragama di Jepang tumbuh subur terbukti dengan banyaknya komunitas-komunitas keagamaan yang muncul sepanjang sejarah perkembangan religi di Jepang. Secara umum diketahui, di samping agama-agama besar seperti Shinto, Budhisme, Confusianisme dan lainnya, di Jepang juga tumbuh sekte-sekte yang merupakan interpretasi dari ajaran-ajaran religi besar tersebut. Bahkan dengan berkembangnya dunia modern sekarang ini, tumbuh subur pula gerakan agama baru yang lebih berorientasi pada ajaran-ajaran praktis. Ichiro Hori, (1968), Folk Religion in Japan, Chicago and London: The University of Chicago Press, hlm. 49-64; Michio Ochi, (1998), Regioous Freedom and the New Mellenium, Tokyo: Proceeding in Internasional Coalition of Religious Freedom, 1-12; Tasuku Matsuo, 2012, Religion and Law in Japan: A Brief Sketch of Japanese History, Tradition, and Cases, Japan: Nineteenth Annual International Law and Religion Symposium at Brigham Young University October 2012, hlm. 1-26.

2 Andrew B. Van Winkle, (2012), "Separation Of Religion And State In Japan: A Pragmatic Interpretation of Articles 20 And 89 of The Japanese Constitution," Pacific Rim Law \& Policy Journal Association, Vol. 21, No. 2, Desember 2012, hlm. 363-370;
} 
kewarganegaraan, memilih tempat tinggal dan meninggalkannya serta berhak kembali ke Indonesia. Kebebasan beragama dipertegas kembali dalam Pasal 29 Undang-Undang Dasar Negara Republik Indonesia Tahun 1945 yang menyebutkan bahwa Negara menjamin kemerdekaan tiap-tiap penduduk untuk memeluk agamanya masing-masing serta beribadat menurut agama dan kepercayaan yang dianutnya. ${ }^{3}$

Legalisasi dalam konstitusi Indonesia kiranya cukup untuk menunjukkan bahwa agama mempunyai kedudukan yang sangat penting di negara ini. Kebebasan beragama merupakan kebebasan beribadat menurut agama dan kepercayaan yang dianutnya. Di negara Indonesia setiap warga negara diwajibkan untuk menganut salah satu agama atau aliran kepercayaan yang telah disahkan oleh negara, tetapi, kebebasan tersebut tidak bermakna kebebasan untuk tidak memiliki agama. ${ }^{4}$ Hal ini sangat berbeda dengan negara-negara liberal yang memberikan kebebasan beragama bagi warga negaranya tetapi juga memberikan kebebasan bagi warga negaranya untuk tidak menganut agama (atheis) tertentu.

Namun, tidak halnya di Negara Indonesia, dalam Pasal 4 dan Pasal 22 Ayat (1) dan Ayat (2) Undang-Undang Nomor 39 Tahun 1999 tentang Hak Asasi Manusia menentukan bahwa agama merupakan suatu hak yang tidak dapat dihapuskan atau dihilangkan dalam keadaan apapun dan oleh pihak manapun. Namun, negara memberikan kebebasan kepada masyarakat untuk menganut agama yang dipercayainya, akan tetapi tidak dapat menentukan atau memaksakan seseorang untuk memilih atau tidak memilih agama dan aliran kepercayaan tertentu. $^{5}$

Keberagaman beragama di Indonesia salah satu bagian daripada cerminan hak asasi yang tidak boleh dihilangkan dan dikekang dalam kondisi apa pun. Namun, kebebasan tanpa batas dapat menimbulkan sikap arogansi dan memandang agama lainya rendah sehingga hal ini dapat membahayakan kerukunan umat beragama. Perkembangan teknologi informasi dan komunika yang sangat pesat telah memberikan peluang sebebas-bebasnya kepada semua pemeluk agama untuk menyiarkan, menyebarkan atau mendakwahkan agamanya. Namun, kebebasan berkeyakinan sering disalahgunakan sehigga media virtual yang dianggap sangat efektif menyebarkan ajaran agama dengan menyampaikan pesan perdamaian justru

\footnotetext{
${ }^{3}$ Bani Syarif Maula, (2013), "Religious Freedom In Indonesia Between Upholding Constitutional Provisions and Complying with Social Considerations," Journal Of Indonesian Islam, Volume 07, Number 02, December 2013, hlm. 383- 403.

${ }^{4}$ Al Makin, (2017), "Not A Religious State; A study of three Indonesian Religious Leaders on The Relation of State And Religion," Journal Indonesia and the Malay Word, Vol. 45, October 2017, hlm. 1-22.

${ }^{5}$ Heiner Bielefeldt, (2012), Freedom of Religion or Belief: A Human Right under Pressure, Oxford Journal of Law and Religion, Volume 1, Issue 1, 1 April 2012, hlm. 15-35.
} 
dimanfaatkan oleh penganut agama tertentu untuk menyebarkan kebencian, non toleran, diskriminatif, kebencian, menghina, provokatif dan tindakan yang sangat ironis yaitu melakukan penistaan terhadap agama tertentu.

Berdasarkan riset Setara Institute, sepanjang tahun 1965 hingga tahun 2017 terdapat 97 kasus penistaan agama. Kasus penistaan agama yang terjadi sebelum reformasi hanya 9 perkara, namun setelah reformasi bergulir pada tahun 1998, jumlahnya kasus penistaan agama membengkak hingga menjadi 88 perkara. Namun, kelompok agama yang paling banyak dinodai adalah Islam yakni 88 kasus, sedangkan penistaan terhadap agama Kristen hanya 4 kasus, Katolik 3 kasus, dan Hindu 2 kasus. ${ }^{6}$ Menurut Ketua Umum Yayasan Lembaga Bantuan Hukum (YLBHI), Asfinawati menyebut bahwa pada bulan Mei 2020 terdapat 38 kasus penodaan agama di Indonesia. Menurut Asfina, ada tren terbaru bahwa pelaku penistaan agama terbanyak berusia di bawah 18 tahun karena bermain aplikasi media sosial TikTok yang berbasis di negeri tirai bambu, Tiongkok (China). ${ }^{7}$

Beberapa kasus berkaitan dengan penistaan agama di Indonesia menjadi perhatian publik. Misalnya, kasus mengenai penistaan agama yang cukup fenomenal adalah kasus dari mantan Gurbenur DKI Jakarta Basuki Tjahaja Purnama (Ahok) yang melakukan penistaan agama pada saat melakukan kunjungan kerja di Pulau Pramuka, Kepulauan Seribu. Pidato Ahok beredar luas di media sosila dimana di dinilai menistakan Agama Islam dengan mengutip dan menafsirkan secara serampangan Al-Qur`an Surah Al Maidah Ayat $51 .{ }^{8}$ Selain itu, ada kasus serupa terjadi di Bali, Donald Ignatius Soeyanto Baria secara sengaja menghina para Ulama dan Kyai melalui akun media sosialnya. ${ }^{9}$ Kemudian, melalui akun sosial medianya, Reza Hazuwen menghina Nabi Muhammad Shalallaahu 'Alayhi Wasallam dan menghina umat Islam ketika mengucapkan kalimat takbir. ${ }^{10}$ Bahkan, penceramah kondang, Ustadz Abdul Somad pernah dilaporkan oleh penganut Agama Kristen karena ceramah beliau telah tersebar luas di dunia maya yang dinilai mengandung penistaan Agama Kristen. ${ }^{11}$

6 Dipna Videlia Putsanra, (2018), Setara: Jumlah Kasus Penistaan Agama Membengkak Usai Reformasi, Setara: Jumlah Kasus Penistaan Agama Membengkak Usai Reformasi - Tirto.ID, Diaksen Pada 6 April 2021.

${ }^{7}$ Yulida Medistiara, (2020), YLBHI Catat 38 Kasus Penodaan Agama hingga Mei, Ada yang Jerat ABG, https://news.detik.com/berita/d-5141781/ylbhi-catat-38-kasus-penodaan-agama-hingga-mei-ada-yangjerat-abg, Diakses Pada 6 April 2021.

${ }^{8}$ Kresna Adi Prasetyo dan Ridwan Arifin, (2019), "Analisis Hukum Pidana Mengenai Tindak Pidana Penistaan Agama Di Indonesia,” Gorontalo Law Review, Volume 2 No. 1, April 2019, hlm. 3.

${ }^{9}$ Ibid.

${ }^{10}$ Ibid.

${ }^{11}$ Novi Yanti Wulan Sari, Anisatul Afifa, Alya Nur, (2019), "Analisis Framing Pemberitaan Kasus Dugaan Penistaan Agama Ustadz Abdul Somad Dalam Kompas TV," Jurnal Communicology, Vol. 7, No. 2, Desember 2019, hlm. 222 - 235 . 
Kasus-kasus seperti ini marak sekali terjadi di dunia maya, bahkan pelakunya masih berusia muda dan masih dalam dunia pendidikan.

Untuk menjaga keharmonisan dan toleransi beragama di Indonesia, pemerintah telah menerbitkan beberapa peraturan perundang-undangan untuk mengatur dan menertibkan serta menjaga kerukunan antar umat beragama dari gangguan berbagai pihak termasuk dari pengguna dunia virtual yang begitu mudah membuat dan mengupload gambar, video, tulisan yang menistakan angama tertentu. Nemun, penegakkan hukum terhadap pelaku penistaan agama, penegakan hukum umumnya menggunakan Undang-Undang Nomor 1 Tahun 1946 tentang Pengaturan Hukum Pidana dan Undang-Undang Nomor 19 Tahun 2016 tentang Perubahan Atas Undang-Undang Nomor 11 Tahun 2008 tentang Informasi Transaksi Elektronik. Artikel ini akan menganalisis berbagai ketentuan yang dapat digunakan untuk menjerat pelaku tindak pidana penistaan agama di Indonesia.

Penelitian yang membahas tentang kejahatan penistaan agama sudah pernah dilakukan oleh peneliti-peneliti sebelumnya. Bahkan beberapa penelitian tersebut telah dipublikasi diberbagai buku dan jurnal. Hal ini sesuai dengan penelusuran yang dilakukan dengan cara melihat beberapa literature yang ada, maka setidaknya ditemukan dua literatur yang erat kaitannya dengan permasalahan yang ada dalam penelitian ini, yaitu Septiani pada tahun 2017 pernah meneliti dan mempublikasikan hasil penelitiannya di Jurnal Syariah yang berjudul Tindak Pidana Penistaan Agama Perspektif Hukum Islam dan Hukum Positif Indonesia. ${ }^{12}$

Dalam penelitiannya membahas tentang bagaimana pengaturan tindak penistaan agama dalam perspektif hukum Islam dan bagaimana pula pengaturannya dalam aspek hukum Indonesia. Penelitian ini mengkaji aspek hukum semata (doctrinal) dengan menggunakan pendekatan perbandingan (comparative) antara kedua sumber hukum yang berbeda. Peneliti lebih memfokuskan kepada eksplorasi hukum materil yang mengatur tindak pidana penistaan agama baik dari perspektif hukum Islam maupun hukum positif Indonesia.

Perbedaan dengan penelitian ini adalah permasalahan yang diangkat bukan hanya menganalisis hukum materilnya tetapi juga membahas tentang dasar hukum kebebasan agama, penafsiran tentang istilah penistaan agama dan membahas secara kritis tentang konsekuensi hukum bagi pelaku tindak pidana penistaan agama di Indonesia. Oleh karena itu, walaupun tidak secara mendalam, penelitian ini menguraikan berbagai kasus yang dijadikan

${ }^{12}$ Rina Septiani, (2017), "Tindak Pidana Penistaan Agama Perspektif Hukum Islam dan Hukum Positif Indonesia." Syariah: Jurnal Ilmu Hukum dan Pemikiran, Vol. 17, No. 1, hlm. 17-31. 
sebagai sampel penetian supaya terlihat jelas benturan antara das sollen dengan das sein dalam suatu penanganan perkara penistaan agama di Indonesia.

Selain itu, penelitian terdahulu terhadap kejahatan penistaan agama juga pernah dilakukan oleh Rumadi pada Tahun 2007 yang berjudul Delik Penodaan Agama dan Kehidupan Beragama dalam RUU KUHP. ${ }^{13}$ Penelitian ini hanya mengkaji dan menguraikan unsur-unsur tindak pidana penodaan agama di dalam Rancangan Undang-Undang Kitab Undang-Undang Hukum Pidana (KUHP). Selain itu, penelitian ini juga mengkritisi pengaturan terhadap kejahatan penodaan agama yang terdapat di dalam KUHP dan membandingkannya dengan rumusan kejahatan penodaan agama di dalam RKUHP.

Dalam penelitian ini, permasalahan yang diteliti adalah bagaiamana pengaturan kebebasan beragama di Indonesia, konsep penistaan agama dan konsekuensi hukum bagi pihak yang melanggarnya. Penelitian ini tidak membahas tentang rumusan kejahatan penistaan agama dalam perspektif RKUHP, melainkan penelitian ini memfokuskan kepada konsep penistaan agama, aturan-aturan yang masih berlaku dan konsekuensi hukum terhadap pelaku kejahatan penistaan agama sehingga penelitian ini dapat menguraikan secara runut berbagai ketentuan tentang penistaan agama dan memberikan beberapa contoh kasus penistaan agama yang sudah mendapat keputusan inkracht van gewijsde dari pengadilan.

\section{RUMUSAN MASALAH}

Berdasarkan latar belakang masalah di atas, maka rumusan masalah yang ditawarkan dalam penelitian ini adalah:

1. Bagimanakah konsep penistaan agama di Indonesia?

2. Bagaimanakah pengaturan kebebasan beragama di Indonesia?

3. Apakah konsekuensi hukum terhadap pelaku kejahatan penistaan agama di Indonesia?

\section{METODE PENELITIAN}

Penelitian Ilmu hukum berusaha untuk menampilkan hukum secara integral sesuai dengan kebutuhan kajian ilmu hukum itu sendiri, sehingga metode penelitian dibutuhkan untuk memperoleh arah penelitian yang komprehensif. ${ }^{14}$ Ilmu hukum memiliki ciri-ciri

${ }^{13}$ Rumadi, (2007), Delik Penodaan Agama dan Kehidupan Beragama dalam RUU KUHP, Jakarta: Yayasan Tifa, hlm 15.

${ }^{14}$ Yati Nurhayati, "Perdebatan Metode Normatif dengan Metode Empirik Dalam Penelitian Ilmu Hukum Ditinjau Dari Karakter, Fungsi dan Tujuan Ilmu Hukum”, Jurnal Al Adl, Volume 5 Nomor 10, 2013, hlm. 15 . 
sebagai ilmu yang bersifat preskriptif dan terapan. Dalam preskriptif, ilmu hukum mempelajari tujuan hukum, nilai-nilai keadilan dalam suatu hukum, baik buruk suatu aturan hukum, konsep-konsep dan norma hukum. sedangkan dalam ilmu terapan, ilmu hukum menetapkan suatu prosedur, ketentuan-ketentuan dan batasan-batasan dalam menegakan suatu aturan hukum. ${ }^{15}$

Metode penelitian yang akan digunakan dalam penulisan hukum ini adalah penelitian normatif. Metode penelitian hukum normatif dapat dimaknai sebagai penelitian hukum dalam tataran norma, kaidah, asas-asas, teori, filosofi, dan aturan hukum guna mencari solusi atau jawaban atas permasalahan baik dalam bentuk kekosongan hukum, konflik norma, atau kekaburan norma. Dengan demikian metode penelitian hukum normatif memiliki karakteristik sebagai penelitian kepustakaan atau literature research yang berbeda dengan metode penelitian empiris (non-doktrinal) yang berkarakteristik penelitian lapangan (field study). ${ }^{16}$

Jenis penelitian hukum normatif dengan menggunakan pendekatan konsep (concept approach), kasus (cases approach) dan undang-undang (statute approach). Pendekatan konsep digunakan untuk mengetahui dan membahas konsep penistaan agama yang terjadi didunia virtual. Manakala pendekatan kasus digunakan untuk menelaah beberapa kasus berkenaan dengan kejahatan penistaan agama. Sedangkan, pendekatan undang-undang bertujuan untuk mengakaji dan menganalisis secara sistematis berbagai fakta, prinsip-prinsip, konsep, teori, undang undang tertentu sehingga menemukan ilmu pengetahuan dan ide-ide baru untuk disarankan menjadi suatu perubahan atau pembaharuan. ${ }^{17}$ Data penelitian ini bersumber dari data sekunder dan diolah secara kualitatif untuk mendeskripsikan suatu fakta, dokumen dan informasi lainnya yang bersifat deskriptif tentang suatu fenomena atau permasalahan yang terjadi di lingkungan masyarakat. ${ }^{18}$ Dalam penelitian ini akan dikaji semua fakta dan undang-undang yang berhubungan dengan penistaan agama yang terjadi didunia virtual di Indonesia.

\section{PEMBAHASAN}

\footnotetext{
${ }^{15}$ Yati Nurhayati, Pengantar Ilmu Hukum, Nusa Media, Bandung, 2020, hlm. 9.

${ }^{16}$ Nurhayati, Y., Ifrani, I., \& Said, M. Y. (2021). Metodologi Normatif dan Empiris Dalam Perspektif Ilmu Hukum. Jurnal Penegakan Hukum Indonesia, 2(1), 1-20. https://doi.org/10.51749/jphi.v2i1.14

${ }^{17}$ Rowe, S. E., (2009), "Legal Research, Legal Analysis, and Legal Writing: Putting Law School into Practice," SSRN ELibrary, Vol. 1193, 2000, hlm. 1-19.

${ }_{18}$ Maanen, J. Van., (1979), "Reclaiming Qualitative Methods for Organizational Research: Preface,". Administrative Science Quarterly, Vol. 24, hlm. 520-526.
} 


\section{A. Dasar Hukum Kebebasan Beragama di Indonesia}

Penduduk Indonesia terdiri dari berbagai agama dan aliran kepercayaan yang berbeda-beda. Namun, jumlah penganut atau pemeluk agama terbesar di Indonesia adalah Islam, Kristen, Katolik, Hindu, Buddha dan Khonghucu (Confusius). Selain itu, Negara juga mengakui adanya aliran kepercayaan atau penghayatan kepercayaan dan agama lokal yang dianut oleh sebagian kecil masyarakat Indonesia. Berdasarkan keputusan Mahkamah Konstitusi Nomor 97/PUU-XIV/2016 menyebutkan bahwa aliran kepercayaan, penghayatan kepercayaan atau agama lokal merupakan hak asasi sesorang yang tidak dapat dibatasi dan harus dilindungi. Setiap penganut atau pemeluk aliran kepercayaan dapat menjadi identitas keagamaan seseorang.

Kebebasan menganut agama tertentu di Indonesia dijamin dan dilindungi oleh negara. Menurut Mahfud M.D, Indonesia merupakan sebuah negara yang berketuhanan dan religius yang melindungi semua penganut agama tertentu tanpa membedakan besar dan kecilnya pemeluk agama masing-masing. Oleh karena itu, negara mempunyai kewajiban konstitusional (Constitutional Obligation/ Judicial Review) untuk menjaga kerukunan umat beragama di Indonesia. ${ }^{19}$

Negara memberikan penghormatan dan jaminan terhadap semua agama di Indonesia berdasarkan konstitusi Indonesia yaitu Undang-Undang Dasar Negara Republik Indonesia 1945 (UUD 1945) dan Undang-Undang Nomor 39 Tahun 1999 tentang Hak Asasi Manusia (UU HAM). Dalam aspek kebebasan menganut agama tertentu, ada beberapa ketentuan yang dapat dijadikan landasan, seperti:

a. Pasal 28E Ayat (1) dan Ayat (2) UUD 1945 jo Pasal 22 Ayat (1) UU HAM, yang mengatur berkenaan dengan kebebasan menganut agama dan kepercayaan tertentu;

b. Pasal 28I Ayat (1) UUD 1945 jo Pasal 4 UU HAM mengenai hak beragama sebagai salah satu HAM yang tidak boleh hapuskan dalam keadaan apapun dan oleh pihak manapun;

c. Pasal 29 Ayat (2) UUD 1945 dan Pasal 22 Ayat (2) UU HAM yang menentukan bahwa negara memberikan kebebasan untuk menganut dan mengamalkan agama tertentu bagi setiap warganegaranya dan melaksanakan ibadah sesuai dengan ajaran agamanya masing-masing.

Selain itu, negara menjamin perlindungan dalam menjalankan ibadah keagamaan yang dipeluknya sebagaimana yang diatur dalam Pasal 28D, Pasal 28E, Pasal hlm. 2 .

\footnotetext{
${ }^{19}$ Mahfud MD, (2010), Politik Hukum Dalam Sistem Hukum Nasional, Varia Peradilan, Vol. XXV,
} 
28G, Pasal 28I dan Pasal 28J UUD 1945. Dalam berbagai instrumen tersebut dapat disimpulkan bahwa:

1. Semua warga negara berhak atas kebebasan berpikir, berkeyakinan dan beragama. Seseorang bebas memilih agama tertentu yang diyakini kebenarannya tanpa ada intervensi atau pemaksaaan dari pihak manapun. Selain itu, setiap pemeluk agama tertentu bebas melaksanakan ritual ibadah keagamaan baik di tempat umum maupun tempat tertutup;

2. Tidak seorang mempunyai kewenangan untuk memaksa seseorang memeluk agama tertentu atau pindah dari agama satu kepada ajaran agama lainnya;

3. Kebebasan beragama hanya dapat dibatasi oleh negara sekiranya ada perintah hukum atau undang-undang. Pembatasan kebebasan beragama oleh hukum bertujuan untuk melindungi keamanan dan ketertiban dalam kebebasan beragama.

Dalam UU HAM banyak ketentuan yang mengatur tentang hak kebebasan beragama dan berkeyakinan, misalnya Pasal 22 Ayat (1) yang menentukan bahwa "Setiap orang bebas menganut agamanya masing-masing dan untuk beribadah menurut agama dan kepercayaannya itu”. Dalam Ayat (2) pada Pasal yang sama mengatur "Negara menjamin kemerdekaan setiap orang memeluk agamanya dan untuk beribadah menurut agama dan kepercayaannya itu". Instrumen ini mengatur secara eksplisit bahwa penganutan terhadap agama dan aliran kepecayaan tertentu adalah hak sesorang yang harus dilindungi dan dijaga serta dihormati oleh negara.

Salah satu hak dasar dalam beragama ialah setiap orang atau pihak manapun bahkan negara sekalipun tidak dibenarkan bersikap diskriminatif dalam semua aspek keagamaan. Dalam Pasal 3 Ayat (3) UU HAM menentukan bahwa "setiap orang berhak atas perlindungan hak asasi manusia dan kebebasan dasar manusia, tanpa diskriminasi”. Undang-Undang ini mempertegas prinsip non derogable rights, dimana hak asasi manusia, termasuk hak keagamaan tidak dapat dihapus oleh siapapun dan kapanpun. Dalam Pasal 4 UU HAM lebih dipertegas lagi bahwa:

"Hak untuk hidup, hak untuk tidak disiksa, hak kebebasan pribadi, pikiran dan hati nurani, hak beragama, hak untuk tidak diperbudak, hak untuk diakui sebagai pribadi dan persamaan di hadapan hukum, dan hak untuk tidak dituntut atas dasar hukum yang berlaku surut adalah hak asasi manusia yang tidak dapat dikurangi dalam keadaan apapun dan oleh siapapun."

Indonesia adalah salah satu Negara yang melakukan pemisahan antara agama dengan Negara. Namun, pemisahan itu tidak bersifat mutlak karena beberapa undangundang yang dibentuk justru bersumber dari agama Islam dan negara memberikan peluang kepada beberapa daerah untuk melaksanakan hukum Islam dalam 
penyelenggaraan pemerintah daerah, seperti di Provinsi Aceh yang mayoritas penduduknya beragama Islam. ${ }^{20}$ Namun, Indonesia bukan lah Negara agama atau Negara yang anti kepada agama. ${ }^{21}$ Indonesia merupakan Negara berdasarkan Pancasila yang lebih mendekati kepada sistem negara sekularisme yang memisahkan antara urusanurusan negara atau politik dan urusan-urusan agama. Pemisahan bukan berarti permusuhan negara atas agama, tetapi netralitasnya dalam urusan-urusan agama. ${ }^{22}$

Gagasan sekularisasi pernah disampaikan oleh Nurcholis Madjid yang memisahkan antara kepentingan agama dan negara. ${ }^{23}$ Dia pernah menyatakan bahwa negara merupakan salah satu segi kehidupan duniawi yang dimensinya adalah rasional dan kolektif. Sedangkan agama merupakan aspek kehidupan lain (ukhrawi) yang dimensinya adalah spiritual pribadi. Gagasan ini langsung mendapat kritik dari Prof. Rasjidi. Salah satu kritik yang tajamnya seperti "Agama Islam tidak hanya berdimensi spiritual dan personal saja, tetapi sekaligus juga berdimensi duniawi, sosio-kolektif". Hal ini seperti iman yang menjadi motor penggerak untuk melakukan karya sosial. ${ }^{24}$ Dengan demikian pada dasarnya, antara agama dan negara memang secara fitrah tidak bisa saling memisahkan diri.

Menurut Zainuddin, sekularisme adalah satu model hubungan negara dan agama, yang menjadi penengah di antara model "negara agama" (teokratis) dan model "negara yang anti dengan agama” (atheis). Dasar negara Indonesia bukan Islam, meskipun

\footnotetext{
${ }^{20}$ Misalnya, secara nasional, pemerintah telah menerbitkan Undang-Undang No. 1 Tahun 1974 tentang Perkawinan. Substansi undang-undang ini bersumber dari hukum islam yang berhubungan dengan perkawinan, perceraian, waris, talak dan lain-lain. Selain itu, Negara memberikan peluang kepada provinsi yang mempunyai status otonomi khusus untuk melaksanakan hukum islam dalam menyelenggarakan pemerintahannya. Misalnya, pemerintah menerbitkan Undang-Undang Nomor 11 Tahun 2006 tentang Pemerintahan Aceh, dimana undangundang tersebut secara eksplisit menyebutkan bahwa Aceh merupakan provinsi yang menerapkan Syari at Islam secara menyeluruh (Kaffah) dalam kehidupan social, hukum, budaya, politik dan pemerintahan.

${ }^{21}$ Ihsan Ali-Fauzi, (2012), Samsu Rizal Panggabean, Husni Mubarok dan Titik Firawati, Mengelola Keragaman: Pemolisian Kebebasan Beragama di Indonesia, Yayasan Wakaf Paramadina Magister Perdamaian dan Resolusi Konflik (MPRK), Yogyakarta: UGM The Asia Foundation, hlm. 51.

${ }^{22}$ Hilmi Muhammadiyah, (2015), "The Relation between Religion and State in Indonesia," Asian Social Science, Vol. 11, No. 28, Januari 2015, hlm. 98-108.

${ }^{23}$ Munir A. Muin, (2015), "Nurcholish Madjid's Idea of Inclusive Theology in Islam," Islamika Indonesiana, Vol. 1, No. 1, 2014, hlm. 55; Mun'im Sirry, (2007), "Secularization In The Mind Of Muslim Reformists: A Case Study of Nurcholish Madjid and Fouad Zakaria," Journal Of Indonesian Islam, Volume 01, Number 02, December 2007, hlm. 323-355.

${ }^{24}$ Buku yang dapat dibaca mengenai pemikiran Nurcholis Madjid, Islam, Kemodernan dan Keindonesiaan, Bandung: Mizan, 1989: Nurcholis Madjid, Islam, Doktrin dan Peradaban, Jakarta: Yayasan Paramadina, 1992. Sedangkan buku pengkritik dari pemikiran Nurcholis adalah Rasjidi, Koreksi terhadap Drs Nurcholis Madjid tentang Sekularisasi, Jakarta: Bulan Bintang, 1977; Faisal Ismail, Sekularisasi: Membongkar Kerancauan Pemikiran Nurcholis Madjid, Yogyakarta: Yayasan Nawesea, 2008. Faiq Tobroni, (2010), "Keterlibatan Negara dalam Mengawal Kebebasan Beragama/Berkeyakinan (Komentar Akademik atas Judicial Review UU No.1/PNPS/1965)," Jurnal Konstitusi, Volume 7, Nomor 6, Desember 2010, hlm. 97-112.
} 
mayoritas penduduknya beragama Islam. Namun, berdasarkan konsep ketuhanan yang terdapat dalam Pancasila khususnya pada sila pertama yang berbunyi: "Ketuhanan Yang Maha Esa", telah menempatkan agama sebagai bagian yang terpenting dalam penyelenggaraan pemerintahan dan mengakui Agama Islam, Kristen, Katolik, Hindu, Budha dan Konghuchu sebagai agama resmi di Indonesia. ${ }^{25}$

Berdasarkan itu Negara mempunyai kewenangan untuk mengatur kebebasan dan keberagaman agama dalam menjalankan ibadah dan kepercayaannya masing-masing. Menurut Hazairin, negara hanya bertugas menjamin kerukunan umat beragama melaksanakan peribadatannya. Sedangkan mengenai keabsahan peribadatan suatu agama diserahkan kepada masing-masing institusi agama yang mempunyai kewenangan dan kompetensi yang dinilai mempunyai kemampuan untuk mengatur hal-hal yang berhubungan dengan agama dan kepercayaannya masing-masing. ${ }^{26}$

Melalui Kementerian Agama, ${ }^{27}$ pemerintah bertanggungjawab sepenuhnya untuk mengatur, menjaga dan mengayomi semua agama dan aliran kepercayaan yang ada di Indonesia. Dalam Undang-Undang Nomor 39 Tahun 2008 tentang Kementerian Negara menyebutkan bahwa Kementerian Agama memiliki tugas pokok dan fungsi secara umum adalah melakukan bimbingan dan pembinaan dalam pembangunan di bidang agama dan keagamaan, baik yang menyangkut kehidupan beragama maupun yang menyangkut pendidikan agama dan keagamaan. Tugas pokok dan fungsi ini dijabarkan dalam bentuk lima program pokok, yaitu peningkatan kualitas kehidupan beragama, peningkatan kualitas kerukunan umat beragama, peningkatan kualitas pendidikan agama dan keagamaan, peningkatan kualitas penyelenggaraan ibadah haji dan umrah, dan peningkatan tata kelola pemerintahan.

Tugas pokok dan fungsi tersebut di atas, semuanya diarahkan pada bimbingan dan pembinaan yang terkait dengan semua agama, yang meliputi Agama Islam, Kristen, Katolik, Hindu, Budha dan bahkan Konghucu. Bagi Kementerian Agama tidak ada

\footnotetext{
${ }^{25}$ M. Zainuddin, (2015), Plurality of Religion: Future Challenges of Religion and Democracy in Indonesia," Journal of Indonesian Islam, Volume 09, Number 02, December 2015, hlm. 151-166.

${ }^{26}$ Hazairin, (1973), Demokrasi Pancasila, Jakarta: Tintamas, hlm. 18-19.

${ }^{27}$ Kementerian Agama pada awal pembentukkannya disebut Departemen Agama. kementerian Agama dibentuk pada tanggal 3 Januari 1946 dengan Menteri Agama Pertama HM Rasyidy. Kelahiran Kementerian Agama adalah atas usul tokoh-tokoh nasional, sebagai kelanjutan dari adanya lembaga kepenghuluan yang mengurusi bidang agama dan keagamaan di hampir seluruh wilayah di Indonesia. Pendiriannya pun tidak pernah mendapat tantangan dari masyarakat, khususnya umat beragama dari semua agama (Islam, Kristen, Katolik, Hindu, Budha, dan Konghucu). Cholis Akbar, (2014), H.M Rasjidi dan Sejarah Kementerian Agama, https://www.hidayatullah.com/kajian/sejarah/read/2014/09/23/29986/h-m-rasjidi-dan-sejarah-kementerianagama-2.html. Diakses pada 20 Februari 2019.
} 
bedanya enam agama yang hidup di Indonesia, sebab semuanya harus dibimbing dan dibina sehingga dapat menjalankan ajaran agamanya dengan baik dan benar serta dapat menjaga hubungan harmonis antara satu penganut agama dengan penganut agama lain. Hal yang membedakannya hanyalah pada jumlah penganut, apabila lebih banyak penganut agama tertentu, maka intensitas bimbingan dan pembinaan secara otomatis akan lebih banyak pula.

Dalam menjalankan fungsi, peranan dan tugasnya, Kementerian Agama harus menjalin koordinasi dengan pemerintahan daerah baik provinsi maupun kabupaten/kota sebagai mitra dalam menjaga keharmonisan umat beragama. Berdasarkan UndangUndang Nomor 9 Tahun 2015 tentang Perubahan Kedua atas Undang-Undang Nomor 23 tahun 2014 tentang Pemerintahan Daerah, setiap provinsi dan pemerintah Kabupaten/Kota diberikan mandat menjaga dan memelihara kerukunan umat beragama di daerahnya. Tugas dan peranan Pemerintah Daerah dalam menjaga keberagaman beragama di Indonesia ini diperkuat lagi dengan Pasal 2 Peraturan Bersama Menteri Agama dan Menteri Dalam Negeri Nomor 8 dan Nomor 9 Tahun 2006 tentang Pedoman Pelaksanaan Tugas Kepala Daerah/Wakil Kepala Daerah dalam Pemeliharaan Kerukunan Umat Beragama, Pemberdayaan Forum Kerukunan Umat Beragama, dan Pendirian Rumah Ibadat yang menyebutkan bahwa pemeliharaan kerukunan umat beragama menjadi tanggung jawab bersama umat beragama, pemerintahan daerah dan Pemerintah pusat.

Ditingkat Provinsi yang bertanggungjawab dalam menjaga kerukunan umat beragama adalah Gubernur, sedangkan ditingkat Kabupaten/Kota yang mempunyai peranan dan tanggungjawab menjaga kebebasan keberagaman beragama adalah Bupati/ Walikota. Pasal 3 dan Pasal 6 Peraturan Bersama Menteri Agama dan Menteri Dalam Negeri Nomor 8 dan Nomor 9 Tahun 2006 menyebutkan bahwa tugas dan kewajiban Gubernur, Bupati dan Walikota dalam menjaga kebebasan keberagaman beragama di Indonesia meliputi:

a. Memelihara ketenteraman dan ketertiban masyarakat termasuk memfasilitasi terwujudnya kerukunan umat beragama;

b. Mengoordinasikan kegiatan instansi vertikal di provinsi dalam pemeliharaan kerukunan umat beragama;

c. Menumbuhkembangkan keharmonisan, saling pengertian, saling menghormati, dan saling percaya di antara umat beragama; 
d. Membina dan mengoordinasikan tugas Gubernur/Wakil Gubernur, Bupati/Wakil Bupati dan Walikota/Wakil Walikota dalampenyelenggaraan pemerintahan daerah di bidang ketenteraman dan ketertiban masyarakatdalam kehidupan beragama;

e. Membina dan mengoordinasikan camat, lurah, atau kepala desa dalam penyelenggaraan Pemerintahan daerah di bidang ketenteraman dan ketertiban masyarakat dalam kehidupan beragama;

f. Menerbitkan izin pendirian rumah ibadat.

Peran aktif kepala daerah/wakil kepala daerah untuk menyadari bahwa tugas pemeliharaan kerukunan di daerah adalah tugas yang dipikulkan kepada kepala daerah/wakil kepala daerah berdasar Undang-Undang Nomor 23 Tahun 2014 tentang Pemerintahan Daerah. Jadi, tugas pemeliharaan kerukunan di daerah bukanlah tugas yang berkaitan dengan doktrin atau pelayanan urusan keagamaan tetapi adalah tugas pemeliharaan keamanan dan ketertiban masyarakat dalam menjalankan ibadah dan kepercayaan suatu agama yang hidup dan berkembang di daerah tersebut.

Tugas melakukan dialog dengan pemuka agama dan tokoh masyarakat, menampung aspirasi dan menyalurkan aspirasi ormas keagamaan dan masyarakat dalam bentuk rekomendasi sebagai bahan kebijakan pemimpin pemerintahan di daerah propinsi, kota dan kabupaten, melakukan sosialisasi peraturan perundang-undangan dan kebijakan di bidang keagamaan yang berkaitan dengan kerukunan umat beragama dan pemberdayaan masyarakat sering kali dilakukan dalam satu paket. Hal ini karena tugastugas tersebut saling terkait satu dengan yang lain dan saling berkesinambungan.

\section{B. Konsep Penistaan Agama di Indonesia}

Salah satu bentuk tindakan yang merusak kebebasan dan kerukunan umat beragama adalah tindakan penodaan agama. Tindakan penodaan agama juga sering disebut dengan penistaan agama. Penodaan agama adalah suatu tindakkan yang merendahkan, menghina, melecehkan, menyebutkan atau melakukan suatu ajaran agama tertentu yang tidak sesuai dengan ajaran agama tersenbut salah satu bentuk delik penodaan agama adalah penghinaan terhadap tuhan (blasphemy atau godslastering) dalam bentuk melukai, merusak, mencemarkan reputasi/ nama baik Tuhan.

Penghinaan ajaran agama ialah suatu hal/ kegiatan yang mengusik ajaran sakral dalam satu agama. Penistaan agama menjadi topik pembicaraan terhangat di masyarakat Indonesia. Hal ini menyebabkan tantangan yang dihadapi Polisi, Majelis Ulama Indonesia bahkan Pemerintah dan masyarakat semakin berat karena disebabkan semakin 
kompleknya permasalahan yang dihadapi umat Islam di negeri ini. Kebebasan yang tidak terbatas akibat reformasi yang disalah artikan telah melahirkan berbagai sikap dan perbuatan yang jauh menyimpang dari norma- norma agama yang sebenarnya.

Secara yuridis penodaan agama merupakan bagian dari delik agama yang memang telah diatur dalam Kitab Undang-Undang Hukum Pidana (KUHP) di Indonesia. Pengaturan tersebut ditujukan untuk menjamin agar negara Indonesia yang multi agama, multi etnik, dan multi ras dapat terhindar dari hal-hal memecah belah, salah satunya konflik-konflik antar umat beragama. Di dalam KUHP sebetulnya tidak ada bab khusus yang mengatur delik agama. Namun ada beberapa delik yang sebenarnya dapat dikategorikan sebagai delik agama. Istilah delik agama sendiri mengandung beberapa pengertian meliputi:

a) delik menurut agama

b) delik terhadap agama;

c) delik yang berhubungan dengan agama.

Kejahatan penghinaan yang berhubungan dengan agama ini dapat dibedakan menjadi 4 (empat) macam, yaitu:

1) penghinaan terhadap agama tertentu yang ada di Indonesia (Pasal 156 huruf a);

2) penghinaan terhadap petugas agama yang menjalankan tugasnya (Pasal 177 angka $1)$;

3) penghinaan mengenai benda-benda untuk keperluan ibadah (Pasal 177 angka 2);

4) menimbulkan gaduh di dekat tempat ibadah yang sedang digunakan beribadah (Pasal 503).

Namun, Pasal yang selama ini sering disebut sebagai Pasal penodaan agama adalah Pasal 156 huruf a KUHP. Perlu diketahui bahwa sebenarnya Pasal 156 huruf a KUHP ini tidak berasal dari Wetboek van Strafrecht $(W v S)$ Belanda, melainkan bersumber dari Penetapan Presiden Nomor 1 Tahun 1965 tentang Pencegahan Penyalahgunaan dan/atau Penodaan Agama (Penpres No.1/1965). Penpres No.1/1965 dalam Pasal 4 menyatakan bahwa:

"Dipidana dengan pidana penjara selama-lamanya lima tahun barangsiapa dengan sengaja di muka umum mengeluarkan perasaan atau melakukan perbuatan: (a) yang pada pokoknya bersifat permusuhan, penyalahgunaan atau penodaan terhadap suatu agama yang dianut di Indonesia; (b) dengan maksud agar supaya orang tidak menganut agama apapun juga, yang bersendi ke-Tuhanan Yang Maha Esa." 
Menurut Surat Edaran Kapolri SE/X/06/2015 dalam Pasal 156 KUHP menentukan bahwa:

"Barangsiapa dimuka umum menyatakan perasaan permusuhan, kebencian atau penghinaan terhadap suatu atau beherapa golongan rakyat Indonesia, diancam dengan pidana penjara paling lama empat tahun atau pidana denda paling banyak empat ribu lima ratus rupiah."

Perkataan golongan dalam Pasal ini dan Pasal berikutnya berarti tiap-tiap bagian dari rakyat Indonesia yang berbeda dengan suatu atau beberapa hagian lainnya karena ras, negeri asal, agama, tempat, asal, keturunan, kebangsaan atau kedudukan menurut hukum tata negara. Penafsiran dan kegiatan tesebut menyimpang kepada agama itu.

Berdasarkan berbagai pendapat tersebut di atas, penodaan atau penistaan agama adalah sebuah perbuatan yang mengandung unsur penghinaan, celaan, atau penodaan pada suatu agama yang pada dasarnya mengutarakan kebencian atau ketidaksukaan secara lisan maupun secara gambar dengan kesengajaan di tempat umum dengan menyinggung berbagai aspek. Dalam perkembangan teknologi informasi dan komunikasi maka perbuatan yang mengandung penodaan atau penistaan agama dapat juga dilakukan di dunia maya dan setiap orang yang melakukan perbuatan tersebut akan dikenakan sanksi pidana berdasarkan Undang-Undang Nomor 11 Tahun 2008 tentang Informasi Transaksi Elektronik.

\section{Kejahatan Penistaan Agama dan Konsekuensi Hukumnya}

Salah satu isu sensitif yang menimbulkan konflik horizontal adalah keberagaman agama. Ada bebagai kasus yang berhubungan dengan isu non toleransi beragama yang menguncang dunia hukum Indonesia, misalnya kasus Cikesik, Ambon, Kupang, Poso dan kasus lainnya. Besarnya dampak negatif dari berbagai kasus di atas, pemerintah harus serius dalam mengambil langkah-langkah yang bersifat antisipatif. Apabila isu intoleransi diabaikan maka akan memicu konflik horizontal yang meluas dan mengorban anak banyak yang tidak berdosa.

Kasus yang menghebohkan masyarakat Indonesia dan terjadinya aksi demonstrasi berjilid-jilid adalah kasus penistaan atau penodaan agama yang dilakukan oleh Gubernur DKI Basuki Tjahaja Purnama (Gubernur Ahok). Kasus ini bermula pada kunjungan kerja Ahok sebagai Gubernur DKI Jakarta dan sekaligus sebagai Calon Pemilihan Kepala Daerah Gubernur DKI Jakarta periode tahun 2018 hingga tahun 2014. Dalam kunjungan kerja tersebut Ahok menyampaikan sambutan. Adapun penggalan sambutannya adalah 
“... jadi jangan percaya sama orang, kan bisa aja dalam hati kecil bapak ibu ga bisa pilih saya, ya kan dibohongi pakai surat Al-Maidah 51, macem-macem itu, itu hak bapak ibu yah jadi kalo bapak ibu perasaan gak bisa kepilih nih karena saya takut masuk neraka karna dibodohin gitu ya engga papa, karna inikan panggilan pribadi bapak ibu program ini jalan saja, jadi bapak ibu gak usah merasa gak enak, dalam nuraninya ga bisa milih Ahok, gak suka sama Ahok nih, tapi programnya gua kalo terima ga enak dong jadi utang budi jangan bapak ibu punya perasaan ga enak nanti mati pelan-pelan loh kena stroke."

Kemudian, pernyataan tersebut beredar dan tersebar luas di dunia maya melalui ungahan akun Buni Yani di salah satu media sosial dengan judul "Penistaan Terhadap Agama?”. Akibatnya, Ahok dilaporkan oleh Majelis Ulama Indonesia (MUI) Sumatera Selatan dan Sekjen Front Pembela Islam (FPI) atas tuduhan melanggar Pasal 156 huruf a KUHP Jo Pasal 28 Ayat (2) Undang-Undang Nomor 11 Tahun 2008 tentang Informasi Transaksi Elektronik.

Laporan atau tuduhan terhadap seseorang melakukan penodaan atau penistaan agama telah menjadi tren di Indonesia. Hampir semua laporan yang berkenaan dengan isu keberagaman beragama dikaitkan dengan penodaan atau penistaan terhadap agama. Secara hukum, tidak ditemukan definisi pasti mengenai perbuatan apa yang dapat disebut sebagai "penodaan suatu agama" dalam putusan-putusan pengadilan. Bahkan, dalam hukum Pidana Indonesia tidak terdapat pengaturan khusus yang mengatur tindak pidana penodaan agama. Namun, secara praktis dalam proses penegakkan hukum ada beberapa ketentuan yang gunakan untuk menjerat pelaku penodaan agama seperti Pasal 156 huruf a KUHP .

Selain itu, Pasal penodaan agama diterapkan untuk berbagai bentuk perbuatan yang dianggap menghina atau menodai agama tertentu yang dirumuskan dalam Penpres No. 1/PNPS/1965 tentang Pencegahan Penyalahgunaan dan/atau Penodaan Agama. Undang-Undang ini tidak memberikan pengertian atau batasan yang jelas mengenai perbuatan apa yang dapat disebut sebagai "penodaan suatu agama". Namun, batasan tentang perbuatan apa yang dapat dan tidak dapat dihukum dengan ketentuan ini hanya ditemukan pada penjelasan Pasal 4 Undang-Undang No. 1/PNPS/1965, yang menyebutkan bahwa "delik yang dimaksudkan disini, adalah semata-mata ditujukan kepada niat untuk memusuhi atau menghina". Penjelasan tersebut tidak menguraikan tentang tindakan-tindakan yang menodai agama, tetapi memberikan pengertian tentang maksud menodai agama. Lebih jauh, penjelasan tersebut mendukung penafsiran atas niat yang dipersyaratkan sebagaimana uraian di atas. Hal ini menafsirkan "pada pokoknya" 
sebagai "semata-mata" dan membuat jelas bahwa suatu tindakan harus secara khusus ditujukan dengan maksud untuk menghina atau melakukan permusuhan.

Undang-undang tersebut di atas menegaskan bahwa perlindungan hukum harus diberikan kepada pemeluk agama yang agamanya dinodai seperti yang terdapat beberapa Pasal di bawah ini:

a. Pasal 1: "Setiap orang dilarang dengan sengaja di muka umum menceritakan, menganjurkan atau mengusahakan dukungan umum, untuk melakukan penafsiran tentang sesuatu agama yang dianut di Indonesia atau melakukan kegiatan-kegiatan keagamaan yang menyerupai kegiatan-kegiatan keagamaan dari agama itu; penafsiran dan kegiatan mana menyimpang dari pokok-pokok ajaran agama itu."

b. Pasal 2, Ayat (1): "Barangsiapa melanggar ketentuan tersebut dalam Pasal 1 diberi perintah dan peringatan keras untuk menghentikan perbuatannya itu di dalam suatu keputusan bersama Menteri Agama, Menteri/Jaksa Agung dan Menteri Dalam Negeri”. Pasal 2 Ayat (2) “Apabila pelanggaran tersebut dalam Ayat (1) dilakukan oleh organisasi atau sesuatu aliran kepercayaan, maka Presiden Republik Indonesia dapat membubarkan organisasi.”

c. Pasal 3: "Apabila, setelah dilakukan tindakan oleh Menteri Agama bersama-sama Menteri/Jaksa Agung dan Menteri Dalam Negeri atau Presiden Republik Indonesia menurut ketentuan dalam Pasal 2 terhadap orang, organisasi atau aliran kepercayaan, mereka masih terus melanggar ketentuan-ketentuan dalam Pasal 1, maka orang, penganut, anggota dan/atau anggota pengurus organisasi yang bersangkutan dari aliran itu dipidana dengan pidana penjara selama-lamanya 5 tahun."

Undang-Undang ini menunjukkan perlindungan hukum kepada pemeluk agama di Indonesia yang diberikan kepada siapapun yang melanggar dan melakukan perbuatan baik perorangan atau kelompok sehingga perbuatan tersebut jelas nantinya jika memenuhi unsur dalam undang-undang itu, Kegiatan dan perbuatan yang dilakukan belum dengan serta merta menjadi pidana penodaan agama akan tetapi jika diulang setelah ada peringatan keras dan jika menimbulkan permusuhan baru disebut tindakan pidana, jadi terpenuhi unsur-unsur yang terdapat dalam Pasal 3 dan Pasal 4 UndangUndang tersebut. Sebetulnya, Pasal 4 ingin memidana mereka yang mengeluarkan perasaan (atau melakukan perbuatan) didepan umum yang mengandung permusuhan, kebencian dan penodaan agama yang dianut oleh seseorang. Berdasarkan ketentuan tersebut maka seseorang dapat dikriminalisasikan atas tuduhan penodaan agama yang ditujukan terhadap agama tertentu. Hal ini disebabkan dapat mengganggu ketenteraman dan keharmonisan umat beragama dan dapat membahayakan/ mengganggu ketertiban umum. 
Sejak Pasal penodaan agama diberlakukan, telah banyak individu yang dikenakan Pasal tersebut, mulai dari kasus HB Jassin tahun 1968, Arswendo Atmowilonto tahun 1990, Basuki Tjahaja Purnama, pemimpin Gafatar Abdussalam alias Ahmad Musadeq, hingga kasus tuduhan pembakaran Kitab Suci Agama Kristiani (Alkitab) di Papua yang dilakukan oleh salah satu anggota Tentara Nasional Indonesia yang diadili di Pengadilan Militer Jayapura, Papua pada 2017. Kesemuanya dikenakan tuduhan penghinaan dan penodaan agama serta didakwa dengan menggunakan beberapa kententuan seperti Pasal 156 KUHP, Pasal 156 huruf a KUHP dan Pasal 157 KUHP. Namun, apabila penistaan atau penodaan agama tersebut dilakukan melalui media elektronik maka penegak hukum seringnya menggunakan Pasal 28 Ayat (2) Undang-Undang Nomor 11 Tahun 2008 tentang Informasi Transaksi Elektronik.

Sejak 1965 hingga 2000, Pasal 156 huruf a KUHP hanya digunakan sebanyak 10 kali, namun dengan pesatnya atmosfir kebebasan dan demokrasi ketentuan ini semakin sering digunakan setelah reformasi terjadi di Indonesia. Amnesty International mencatat, sejak 2005 terdapat 106 orang didakwa dan diputus menggunakan Pasal tersebut. Persebaran kasus-kasus penodaan agama mencakup hampir separuh provinsi di Indonesia. Crouch mencatat, antara 1965 sampai dengan 2000, kasus-kasus dengan tuduhan Pasal 156 huruf a KUHP mencakupi 14 Provinsi, dengan konsentrasi utama di Pulau Jawa. Sementara Laporan Setara Institute menunjukkan, sejak 1965 sampai 2017 terdapat 97 kasus penodaan agama dengan konteks perbuatan yang sangat beragam. Sebagian besar tuduhan penodaan agama terjadi dalam konteks perbedaan pemahaman keagamaan dan kekeliruan dalam penafsiran dalil dalam ajaran tertentu. Selain itu, laporan tersebut juga menyatakan, dalil penodaan agama dijadikan alat untuk membangun dan mempertahankan status quo bagi kelompok-kelompok keagamaan yang mayoritas di tengah-tengah umat beragama.

Banyaknya permasalahan hukum tentang menjaga kemurnian dan kesucian agama maka Pada 20 Oktober 2009, Undang-Undang Nomor 1/PNPS/1965 diajukan ke Mahkamah Konstitusi (MK) guna diuji konstitusionalitas. Dari Uji Materiil tersebut MK melalui Putusan Nomor 140/PUU-VII/2009 menyebutkan bahwa norma Undang-Undang ini tidak berlawanan konstitusi. Putusan MK menerangkan bahwa undang-undang tersebut benar dan tidak bertentangan dengan kebebasan beragama yang dilindungi UUD 1945. Namun ada pandangan yang menyebutkan bahwa undang-undang tersebut belum begitu baik dalam artian penyusunannya tidak sesuai dengan kaidah dan sistematika 
pembentukan peraturan perundang-undangan. Oleh karena itu, Undang-Undang Perlindungan Agama tersebut harus baik dan benar serta mengurangi atau bahkan meniadakan kekerasan atas nama agama dan penodaan terhadap agama. Walaupun MK dinilai sangat hati-hati dalam membuat putusannya namun MK tetap memutuskan Undang-Undang Penodaan Agama tetap konstitusional dengan berbagai catatan untuk perbaikan. Selain itu, MK juga memerintahkan kepada para pembentuk undang-undang yaitu pemerintah dan DPR untuk memperbaiki beberapa norma yang ada dalam undangundang tersebut.

Pada mulanya, semua aliran hukum yang dianut oleh negara-negara diseluruh dunia tidak terdapat rumusan yang dapat mengkriminalisasi terhadap penistaan atau penodaan agama. Perlu diketahui, Wet Book van Straft Recht $(W v S)$ Belanda sendiri tidak merumuskan secara speksifik tindak pidana tentang agama. namun yang ada hanyalah Undang-Undang mengenai Godslastering 1932 yang lebih dikenal dengan nama Delik Agama (Lex Donner). Undang-Undang ini diilhami dari Undang-Undang Jerman yang disebut sebagai Strafgesetzbuch yang merumuskan delik agama dalam Pasal 166. Tampaknya rumusan Pasal 166 Strafgesetzbuch menjadi model dan diadobsi oleh $W v S$ Negeri Belanda, yang sebelumnya tidak memiliki aturan mengenai delik agama. Dalam peraturan perundang-undangan tersebut menentukan bahwa ucapan, pernyataan ataupun perbuatan-perbuatan yang mengejek Tuhan, Nabi dan lain-lainnya dianggap menistakan agama.

Begitu juga di negara Indonesia, pada mulanya pengaturan mengenai delik agama tidak ada dalam KUHP Indonesia, namun yang ada hanya ketentuan menyangkut dengan kehidupan beragama, seperti ketentuan dalam Pasal 175 KUHP, 176 KUHP dan 177 KUHP. Namun, dalam perkembangan hukum di Indonesia, banyak dijumpai peristiwa hukum yang menodai, melecehkan atau menistakan agama tertentu sehingga menimbulkan kegaduhan, kerusuhan dan pertikaian antara pemeluk agama. Akhirnya tindak pidana penodaan atau penistaan terhadap agama diatur dalam Pasal 156 KUHP dan Pasal 156 huruf (a) KUHP.

Menurut Afriandi, dalam hukum Islam pun kriminalisasi terhadap penodaan agama sebenarnya tidak dijumpai baik dalam Al-Qur'an maupun Hadist. Delik tersebut hanya ada pada instrumen ijtihad para ulama' yang kemudian diinternalisasikan ke dalam Undang-Undang beberapa Negara Islam. Dalam hukum Islam, rumusan hukuman terhadap pelaku penodaan sangat beragam, mulai dari sanksi yang paling ringan seperti 
penjara, hingga sanksi yang paling berat yaitu pidana seumur hidup dan pidana mati. Rujukan para ulama' dalam merumuskan delik penodaan agama ialah dilatarbelakangi oleh masyarakat yang homogen dalam keagamaan. Penghinaan atau penodaan dalam islam dapat berupa seperti menghina atau melecehkan Tuhan, para Nabi, Malaikat, dan Kitab Al-Qu'ran. Penodaan terhadap agama dengan sengaja maka menjadikannya Murtad (riddah), sedangkan sanksinya melihat kepada akibat dan dampak kemurtadanya tersebut.

Menurut Muhammad Dahri, Ibnu Taimiyah membagi riddah (murtad) kepada dua, beliau berkata: "Riddah" itu ada dua macam; Riddah Mujarradah (murni) dan Riddah Mughalladzhah (kelas berat) yang secara khusus disyariatkannya hukuman mati. Jika termasuk Riddah Mughalladzah maka dia dihukum mati, jika tidak bertaubat jika Riddah-nya Mujarradah, karena kebodohan dan lemahnya keyakinan, maka tidak sampai dihukum bunuh akan tetapi di ta'zir (penjara). Kemudian jika perbuatan murtad itu dilakukan dengan berkelompok/aliran, dengan maksud ingin menghina dan merusak agama, kemudian tidak mauruju' ke Islam atau bertaubat maka bersanksi hukuman mati. Hanya saja tidak semua perbuatan penodaan agama membuat dia murtad dengan sanksi dihukum mati, tetapi mesti melihat dampak, motif kemurtadannya dan pelakunya. Maka perbuatan penodaan agama yang sengaja dilakukan dengan motif kebencian secara terang-terangan maka termasuk Murtad Mughallazhah, atau Murtad Harby (menentang), sedangkan penodaan yang tanpa disengaja dan bukan maksud menodai, maka Murtad Muraja'ah atau Jahily.

Al-Qadhi 'Iyadh berpandangan bahwa kesepakatan para ulama dan para Imam ahli fatwa, mulai dari generasi para sahabat berpadangan bahwa mayoritas sepakat, sanksi yang diterapkan kepada pelaku penghinaan terhadap Nabi Shalallaahu 'Alayhi Wasallam adalah hukuman mati. Ini merupakan pendapat Imam Malik, Imam al-Laits, Imam Ahmad Bin Hanbal, Imam Ishaq Bin Rahawih dan Imam as-Syafii. Kholil Ibn Ishaq alJundiy, menerangkan bahwa "barang siapa yang menghina Nabi, melaknat, mengejek, menuduh, merendahkan, melabeli dengan sifat yang bukan sifatnya, menisbatkan hal-hal yang tidak pantas kepadanya, mencela maka hukumannya adalah dibunuh”.

Merujuk kepada uraian tersebut di atas, dinamika keberagaman agama selalu disertai dengan permasalahan, perbedaan, pergesekan antar pemeluk agama yang berujung kepada berbagai tindakan hukum seperti penodaan, penistaan atau penghinaan agama tertentu. Dalam aspek hukum baik hukum Indonesia maupun hukum Islam, penodaan atau penghinaan terhadap ajaran agama tertentu sangat dilarang bahkan 
hukuman yang dikenakan terhadap pelaku penistaan agama tergolong berat. Hal ini dilakukan semata-mata untuk menjaga kerukunan umat beragama yang begitu pluralistik di Indonesia. Semua elemen bangsa harus bersikap bahwa keberagaman agama di Indonesia harus dipandang sebagai aset bangsa yang tidak bernilai harganya. Oleh karena itu, masyarakat bersama pemerintah harus berpartisipasi secara aktif untuk menjaga keutuhan keberagaman beragama dari semua sisi daripada agama itu sendiri.

\section{PENUTUP}

\section{A. Kesimpulan}

1. Kebebasan beragama di atur dalam Pasal 28E, Pasal 28I, dan Pasal 29 UndangUndang Dasar Negara Republik Indonesia Tahun 1945. Selain itu, kebebsan beragama juga diatur di dalam Pasal 4 dan Pasal 22 Ayat (1) dan Ayat (2) UndangUndang Nomor 39 Tahun 1999 tentang Hak Asasi Manusia. Dalam ketentuan tersebut menerangkan bahwa hak beragama yang dimilki oleh setiap warga negara Indonesia merupakan hak asasi yang tidak dapat dikurangi dalam keadaan apapun dan oleh siapapun. Walaupun konstitusi Indonesia sangat menjunjung tinggi kebebsan beragama tetapi kebebasan tersebut tidak bersifat absolut. Pembatasan terhadap kebebasan beragama hanya dapat dilakukan melalui undang-undang dengan tujuan untuk menjaga keharmonisan dan toleransi umat beragama di Indonesia.

2. Secara umum, konsep penistaan agama bukan hanya tindakkan merusak kesuscian agama itu sendiri tetapi juga termasuk perbuatan yang dapat menghina tokoh agama, merusak simbol agama, dan pasilitas beribadah agama tertentu. Penistaan agama dapat berupa tindakan yang merendahkan, menghina, melecehkan, menyebutkan atau melakukan suatu ajaran agama tertentu yang tidak sesuai dengan ajaran agama tersebut. Dalam aspek normatif, kejahatan yang berhubungan dengan penistaan agama dapat dikategorikan seperti penghinaan terhadap agama tertentu yang ada di Indonesia, penghinaan terhadap petugas agama yang menjalankan tugasnya, penghinaan mengenai benda-benda untuk keperluan ibadah dan secara sengaja membuat kegaduhan di dekat tempat ibadah yang sedang digunakan beribadah.

3. Untuk menjerat pelaku penistaan agama di Indonesia, ada beberapa ketentuan yang dapat digunakan seperti KUHP, Undang-Undang Nomor 1/PNPS/1965 tentang Pencegahan Penyalahgunaan dan/atau Penodaan Agama dan Undang-Undang Nomor 19 Tahun 2016 tentang Perubahan Atas Undang-Undang Nomor 11 Tahun 2008 
tentang Informasi Transaksi Elektronik dan Undang-Undang Nomor 40 Tahun 2008 tentang Penghapusan Diskriminasi Ras dan Etnis. Namun, ketentuan yang paling banyak digunakan untuk menjerat pelaku penistaan agama adalah Pasal 156 huruf a KUHP dan Pasal 28 Ayat (2) juncto 45 a Ayat (2) Undang-Undang Nomor 19 Tahun 2016 tentang Perubahan Atas Undang-Undang Nomor 11 Tahun 2008 tentang Informasi Transaksi Elektronik, dimana pelaku dapat mendapatkan hukuman penjara dan denda sesuai tindak pidana yang dilakukannya. Semua norma yang diatur dalam Undang-Undang tersebut memberikan perlindungan terhadap pemeluk agama untuk menjalankan ibadah sesuai dengan kepercayaannya tetapi Undang-Undang memberikan batasan terhadap kebebasan yang merusak, menodai atau menistakan dan menghina agama tertentu dengan tujuan menjaga kesucian agama berkenaan.

\section{B. Saran}

1. Tindakan penistaan agama merupakan salah satu kejahatan yang sensitif di Indonesia. Hal itu disebabkan mayoritas masyarakat Indonesia mengakui dan menganut agama tertentu serta agama yang paling banyak dianut adalah Agama Islam. Walaupun agama lain juga pernah mengalami penistaan terhadap kesucian ajarannya, namun sebahagian besar kasus penistaan agama justru terjadi terhadap Agama Islam. Berkaca kepada beberapa kasus penistaan Agama Islam, seperti kasus mantan Gubernur DKI Jakarta, Basuki Tjahaja Purnama atau lebih dikenal dengan sebutan Ahok, penegak hukum dinilai lamban merespon dalam menangani perkara tersebut sehingga memancing emosi umat Islam dan berujung kepada demonstrasi besar-besaran di Jakarta. Oleh karena itu, disarankan kepada penegak hukum supaya bekerja secara professional dan responsive dalam menangani kasus penistaan agama di Indonesia.

2. Penegakkan hukum terhadap pelaku kejahatan penistaan agama masih menggunaan pendekatan penghukuman sehingga penegakkan hukum sering sekali menggunakan Pasal 156 huruf a KUHP untuk menjerat pelaku penistaan agama. Konsekuensinya adalah pelaku akan mendapat hukuman berupa pemidaan penjara. Seharusnya pendekatan penghukuman harus tidak diutamakan karena pemidanaan tersebut bersifat ultimum remedium. Oleh karena itu, penulis menyarankan supaya pelaku penistaan agama harus diberikan hukuman yang bersifat komulatif berupa hukuman 
pembinaan dan hukuman pemenjaraan, sehingga pelaku kejahatan penistaan agama bukan hanya diberikan hukuman tetapi diberikan pembinaan pemahaman terhadap torelansi beragama. 


\section{Buku}

\section{DAFTAR PUSTAKA}

Amnesty International, (2014), Prosecuting Belief, Jakarta: Indonesia’s Blasphemy Law.

Arief, B. N., (2007), Delik Agama dan Penghinaan Tuhan (Blasphemy) di Indonesia dan Perbandingan Berbagai Negara, Semarang: Penerbit UNDIP.

Hazairin, (1973), Demokrasi Pancasila, Jakarta: Tintamas.

Ibnu Taimiyah, (2016), as-Sharim al-Maslul 'ala Syatimi ar-Rasul, (Juz I), Kaherah: Daar Ibn al-Jawaziy.

Ichiro Hori, (1968), Folk Religion in Japan, Chicago and London: The University of Chicago Press.

Ihsan Ali-Fauzi, (2012), Samsu Rizal Panggabean, Husni Mubarok dan Titik Firawati, Mengelola Keragaman: Pemolisian Kebebasan Beragama di Indonesia, Yogyakarta: UGM The Asia Foundation.

Jalaluddin, (2000), Phiscology Agama, Jakarta: Siantar Press.

M. D. Al-Bugha, (2006). Fikih Islam Lengkap, Jakarta: Media Dzikir.

Michio Ochi, (1998), Regioous Freedom and the New Mellenium, Tokyo: Proceeding in Internasional Coalition of Religious Freedom.

Setara Institute, (2017), Rezim Penodaan Agama 1965-2017, Ringkasan Eksekutif Laporan Riset Tematik Kebebasan Beragama dan Berkeyakinan, Jakarta: Setara Institute.

Tasuku Matsuo, (2012), Religion and Law in Japan: A Brief Sketch of Japanese History, Tradition, and Cases, Japan: Nineteenth Annual International Law and Religion Symposium at Brigham Young University October 2012.

Tim, (2011), Pengkajian Hukum Tentang Perlindungan Hukum Bagi Upaya Menjamin Kerukunan Umat Beragama, Jakarta: Kementerian Hukum dan Hak Asasi Manusia Badan Pembinaan Hukum Nasional.

Yati Nurhayati, (2020), Pengantar Ilmu Hukum, Nusa Media, Bandung.

\section{Peraturan Perundang-Undangan}

Undang-Undang Dasar Negara Republik Indonesia Tahun 1945.

Undang-Undang Nomor 1 Tahun 1946 tentang Pengaturan Hukum Pidana.

Undang-Undang Nomor 39 Tahun 1999 tentang Hak Asasi Manusia. 
Undang-Undang Nomor 9 Tahun 2015 tentang Perubahan Kedua atas Undang-Undang Nomor 23 tahun 2014 tentang Pemerintahan Daerah.

Undang-Undang Nomor 19 Tahun 2016 tentang Perubahan Atas Undang-Undang Nomor 11 Tahun 2008 tentang Informasi dan Transaksi Elektronik.

Penetapan Presiden Nomor 1 Tahun 1965 tentang Pencegahan Penyalahgunaan dan/atau Penodaan Agama.

Peraturan Bersama Menteri Agama dan Menteri Dalam Negeri Nomor 8 dan Nomor 9 Tahun 2006 tentang Pedoman Pelaksanaan Tugas Kepala Daerah/Wakil Kepala Daerah dalam Pemeliharaan Kerukunan Umat Beragama, Pemberdayaan Forum Kerukunan Umat Beragama, dan Pendirian Rumah Ibadat.

\section{Jurnal}

A. Masyhar, (2016), "Relasi Ajaran GAFATAR dengan Ideologi Radikal, Seminar Nasional Hukum, Vol. 2, No. 1.

Adnan, (2017), "Penodaan Agama: Studi Komparatif Hukum Islam dan Hukum Pidana Di Indonesia, “ Al-Qadha: Jurnal Hukum Islam dan Perundang-Undangan, Vol. 4, No. 1.

Al Makin, (2017), "Not A Religious State; A study of three Indonesian Religious Leaders on The Relation of State And Religion," Journal Indonesia and the Malay Word, Vol. 45, Oktober 2017.

Andrew B. Van Winkle, (2012), "Separation Of Religion And State In Japan: A Pragmatic Interpretation of Articles 20 and 89 of The Japanese Constitution," Pacific Rim Law \& Policy Journal Association, Vol. 21, No. 2, Desember 2012.

Bani Syarif Maula, (2013), "Religious Freedom In Indonesia Between Upholding Constitutional Provisions and Complying with Social Considerations," Journal of Indonesian Islam, Volume 07, Number 02, December 2013.

Crouch, M. A., (2012), "Law and Religion in Indonesia: The Constitutional Court and the Blasphemy Law," Asian Journal of Comparative Law, Vol. 7, No. 1.

Faiq Tobroni, (2010), “Keterlibatan Negara dalam Mengawal Kebebasan Beragama/Berkeyakinan (Komentar Akademik atas Judicial Review UU No.1/PNPS/1965),"Jurnal Konstitusi, Volume 7, Nomor 6, Desember 2010.

Faiz, P. M., (2014), “Analisa dari Dr. Melissa Crouch "UU Penodaan Agama dan Mahkamah Konstitusi dimuat pada kolom khazanah," Konstitusi, Vol. 87. 
Heiner Bielefeldt, (2012), Freedom of Religion or Belief: A Human Right under Pressure, Oxford Journal of Law and Religion, Volume 1, Issue 1, 1 April 2012.

Hilmi Muhammadiyah, (2015), "The Relation between Religion and State in Indonesia," Asian Social Science, Vol. 11, No. 28, Januari 2015.

Kresna Adi Prasetyo dan Ridwan Arifin, (2019), “Analisis Hukum Pidana Mengenai Tindak Pidana Penistaan Agama Di Indonesia," Gorontalo Law Review, Volume 2 No. 1, April 2019.

M. Dahri, (2017), “Tindak Pidana Penodaan Agama Di Indonesia: Tinjauan Pengaturan Perundang-Undangan dan Konsep Hukum Islam," At-Tafahum: Journal of Islamic Law, Vol. 1, No. 2.

M. Zainuddin, (2015), Plurality of Religion: Future Challenges of Religion and Democracy in Indonesia," Journal of Indonesian Islam, Volume 09, Number 02, December 2015.

Maanen, J. Van., (1979), "Reclaiming Qualitative Methods for Organizational Research: Preface,". Administrative Science Quarterly, Vol. 24.

Mahfud MD, (2010), Politik Hukum Dalam Sistem Hukum Nasional, Varia Peradilan, Vol. XXV.

MS, A., (2017), "Criminal Law Analysis of Religious Blasphemy Violation in Aceh,” Dejure: Jurnal Penelitian Hukum, Vol. 17, No. 1.

Muktiomo, (2012), "Mengkaji Politik Hukum Kebebasan Beragama dan Berkeyakinan di Indonesia," Jurnal Dinamika Hukum, Vol. 12, No. 2.

Munir A. Muin, (2015), "Nurcholish Madjid's Idea of Inclusive Theology in Islam," Islamika Indonesiana, Vol. 1, No. 1, 2014.

Mun'im Sirry, (2007), "Secularization In The Mind Of Muslim Reformists: A Case Study of Nurcholish Madjid and Fouad Zakaria," Journal Of Indonesian Islam, Volume 01, Number 02, December 2007.

Nurhayati, Y., Ifrani, I., \& Said, M. Y. (2021). Metodologi Normatif dan Empiris Dalam Perspektif Ilmu Hukum. Jurnal Penegakan Hukum Indonesia, 2(1), 1-20. https://doi.org/10.51749/jphi.v2i1. 
Novi Yanti Wulan Sari, Anisatul Afifa, Alya Nur, (2019), “Analisis Framing Pemberitaan Kasus Dugaan Penistaan Agama Ustadz Abdul Somad Dalam Kompas TV," Jurnal Communicology, Vol. 7, No. 2, Desember 2019.

Pultoni, (2012), Panduan Pemantauan Tindak Pidana Penodaan Agama dan Ujaran Kebencian atas Nama Agama, Jakarta: The Indonesian Legal Resounce Center.

Rowe, S. E., (2009), "Legal Research, Legal Analysis, and Legal Writing: Putting Law School into Practice," SSRN ELibrary, Vol. 1193, 2000.

Septiani, R. (2017), "Tindak Pidana Penistaan Agama Perspektif Hukum Islam dan Hukum Positif Indonesia.” Syariah: Jurnal Ilmu Hukum dan Pemikiran, Vol. 17, No. 1.

Yati Nurhayati, (2013), "Perdebatan Metode Normatif dengan Metode Empirik Dalam Penelitian Ilmu Hukum Ditinjau Dari Karakter, Fungsi dan Tujuan Ilmu Hukum”, Jurnal Al Adl, Volume 5 Nomor 10.

Z. Idami, (2016), "Law Protection By A State For Religion Believers In Indonesia And Its Comparison With Islamic Laws," Kanun: Jurnal Ilmu Hukum, Vol. 18, No. 1.

\section{Internet}

Ismuhadi, (2019), Analisa Pidana Hukum dan Kriminologi Terhadap Tindak Pidana di Indonesia. Medan: www.repository.usu.ac.id/bitstream/123456789/12134/1/09E02103.pdf, 